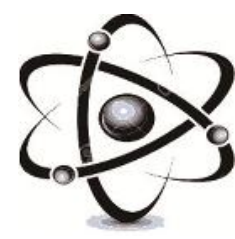

JURNAL RISET FISIKA EDUKASI DAN SAINS

Education and Science Physics Journal

E- ISSN : 2503-3425

P- ISSN : 2407-3563

JRFES Vol 1, No 1 (2014) 42 - 47

http://ejournal.stkip-pgri-sumbar.ac.id/index.php/JRFES

\title{
VALIDITAS PENGEMBANGAN HANDOUT BERBASIS MODEL CONCEPTUAL CHANGE TEACHING PADA PERKULIAHAN FISIKA DASAR DI STKIP PGRI SUMATERA BARAT
}

\author{
Auliya Hidayati ${ }^{(1)}$ Siskha Handayani ${ }^{(2)}$ \\ ${ }^{(1)}$ Prodi Pendidikan Fisika STKIP PGRI Sumatra Barat \\ ${ }^{(2)}$ Prodi Pendidikan Matematika STKIP PGRI Sumatra Barat \\ Email : auliyahidayati38@gmail.com \\ http://dx.doi.org/10.22202/jrfes.2014.v1i1.1185

\section{Astract}

This research is motivated unavailability of teaching materials to support the creation of an effective learning of the students. One of the teaching materials that can be developed is a handout. This research aims to develop a handout conceptual change teaching model based on the material temperature and the heat is valid, practical, and effective. This type of research is the development of research (research and development) using the model proposed by Plomp. The research phase is the phase of preliminary investigations (preliminary research), design and realization phase (prototyping phase), and the phases of assessment (assessment phase). In the initial investigation phase, researchers conducted a preliminary analysis or identification of problems, needs analysis, analysis of the concept or content, and assessment of the necessary literature in learning. In the design and realization phase is to design the course handout for Physics. Additionally do step formative evaluation that includes self evaluation, prototyping (expert reviews, one-to-one and small group), as well as field test. In the assessment phase carried out testing of the handout. In this study tested the validity of the data obtained through the validation sheet handout Basic Physics.

Keywords: validity handout, conceptual change teaching, basic physics

\begin{abstract}
Abstrak
Penelitian ini dilatarbelakangi belum tersedianya bahan ajar yang dapat mendukung terciptanya pembelajaran yang efektif terhadap mahasiswa. Salah satu bahan ajar yang dapat dikembangkan adalah handout. Penelitian ini bertujuan untuk mengembangkan handout berbasis model conceptual change teaching pada materi suhu dan kalor yang valid, praktis, dan efektif. Jenis penelitian yang digunakan adalah penelitian pengembangan (research and development) menggunakan model yang dikemukakan oleh Plomp. Adapun tahap penelitian adalah fase investigasi awal (preliminary research), fase perancangan dan realisasi (prototyping phase), dan fase penilaian (assessment phase). Pada fase investigasi awal, peneliti melakukan analisis awal atau identifikasi masalah, analisis kebutuhan, analisis konsep atau isi materi, dan pengkajian literatur yang diperlukan dalam pembelajaran. Pada fase perancangan dan realisasi dilakukan perancangan handout untuk mata kuliah Fisika Dasar. Selain itu dilakukan langkah formative evaluation yang meliputi self evaluation, prototyping (expert reviews, one-to-one, dan small group), serta field test. Pada fase penilaian dilakukan pengujian terhadap handout. Pada penelitian ini dilakukan uji validitas yang datanya diperoleh melalui lembar validasi handout Fisika Dasar.
\end{abstract}

Kata kunci : validitas handout, conceptual change teaching, fisika dasar 


\section{PENDAHULUAN}

Pendidikan memegang peranan yang sangat penting dalam kelangsungan hidup suatu bangsa. Suatu bangsa akan dihadapkan pada berbagai perkembangan yang terjadi di seluruh aspek kehidupannya. Perkembangan yang terjadi antara lain dalam bidang ekonomi, sosial, budaya, ilmu pengetahuan dan teknologi (IPTEK). Pada saat ini, IPTEK mengalami perkembangan yang sangat pesat. Dalam berbagai kehidupan, orang akan selalu berhadapan dan dibantu oleh hasil-hasil dari perkembangan IPTEK tersebut. Salah satu ilmu pengetahuan penunjang perkembangan teknologi yang dinikmati oleh manusia adalah fisika.

Fisika dipelajari mulai dari pendidikan dasar dan menengah sampai dengan perguruan tinggi. Di perguruan tinggi ilmu fisika dikaji lebih mendalam. Pentingnya mempelajari fisika tidak menjamin mahasiswa senang mempelajarinya, bahkan mereka menganggap fisika sebagai mata kuliah yang sulit. Begitu juga dengan mahasiswa fisika, tidak semua mahasiswa fisika adalah orang-orang yang benar-benar menyukai dan menyenangi fisika. Berbagai alasan mereka kemukakan ketika memilih fisika sebagai kelanjutan belajar di perguruan tinggi.

Berdasarkan hasil wawancara peneliti dengan mahasiswa, diketahui beberapa alasan mahasiswa memilih Program Studi Fisika, diantaranya : (1) takut mempelajari fisika, sehingga mereka ingin mendalami fisika, (2) karena sudah menyenangi fisika sejak sekolah menengah, (3) karena dosen fisika di sekolah menengah sangat ramah dan baik, sehingga mereka tertarik pada fisika dan ingin lebih mendalami fisika di perguruan tinggi, (4) karena dipaksa oleh orang tua, dan (5) karena sarjana fisika mudah mendapatkan pekerjaan atau tidak ada yang menganggur.

Fisika adalah mata kuliah yang diberikan pada tahun pertama perkuliahan fisika. Di STKIP PGRI, perkuliahan Fisika dilaksanakan pada semester pertama. Mata kuliah Fisika merupakan mata kuliah dasar yang menjadi mata kuliah prasyarat untuk beberapa mata kuliah lain di Program Studi Fisika. Sebagai mata kuliah dasar, Fisika wajib diikuti oleh semua mahasiswa Fisika. Tetapi kenyataannya, hasil belajar yang diperoleh mahasiswa untuk mata kuliah Fisika masih belum memuaskan.

Dari pengamatan yang peneliti lakukan, mahasiswa hanya mengerjakan latihan jika latihan itu dikumpul atau akan mengikuti ujian. Bahkan tidak jarang latihan itu hanya mereka salin saja dari pekerjaan temannya yang tergolong pintar. Tentu saja ini mengakibatkan pembelajaran yang berkelanjutan tidak bisa terlaksana dengan maksimal. Penyebab lain adalah buku yang digunakan sebagai sumber belajar belum dimanfaatkan oleh mahasiswa semaksimal mungkin. Hal ini dikarenakan buku yang digunakan cenderung lebih ditekankan pada misi penyampaian materi, tetapi tidak dalam pemahaman materi. Akibatnya, dosen kesulitan menuntaskan materi bab yang direncanakan, karena waktu lebih banyak dipakai untuk menjelaskan materi dan latihan soal.

Untuk mengatasi permasalahan di atas, diperlukan suatu alat yang bisa membiasakan mahasiswa untuk belajar secara berkelanjutan dan terarah berupa sebuah handout. Handout merupakan buku panduan belajar, buku pegangan peserta didik yang berisi pokokpokok materi yang digunakan dalam proses belajar mengajar. Handout diambil dari beberapa literatur yang memiliki relevansi dengan materi yang diajarkan serta kompetensi dasar dan materi pokok yang harus dikuasai oleh mahasiswa. Dengan adanya handout ini maka mahasiswa tidak perlu mencatat kembali penjelasan dari dosen. Handout yaitu: handout dapat berisi penjelasan singkat tentang bahasan, menjelaskan kaitan antar topik, memberikan pertanyaan dan kegiatan pada para pembacanya, dan juga dapat memberikan umpan balik dan langkah tindak lanjut [1].

Dalam pembelajaran Fisika metode ceramah tidak sepenuhnya cocok untuk digunakan karena dalam proses pembelajaran Fisika tidak cukup hanya dengan mendengar 
dan menghafal. Pembelajaran Fisika lebih ditekankan kepada pemahaman konsep. Salah satu model pembelajaran yang menekankan pada pemahaman konsep adalah model pembelajaran Conceptual Change Teaching (CCT) yang dikembangkan oleh Driver and Oldham [2].

Berdasarkan latar belakang yang dijelaskan di atas, peneliti tertarik untuk melakukan penelitian yang berjudul Pengembangan Handout Berbasis Model Conceptual Change Teaching Pada Perkuliahan Fisika Dasar di STKIP PGRI Sumatera Barat.

Berdasarkan latar belakang masalah diatas, maka dapat dirumuskan permasalahan sebagai berikut: Bagaimana mengembangkan handout berbasis model CCT pada mata kuliah Fisika Dasar yang valid, praktis dan efektif?

Berdasarkan rumusan masalah diatas, maka tujuan penelitian adalah sebagai berikut ini.

1. Menghasilkan handout berbasis model CCT yang valid pada mata kuliah Fisika dasar

2. Menghasilkan handout berbasis model CCT yang praktis dan efektif pada mata kuliah Fisika dasar

Produk yang dihasilkan dalam pengembangan handout. Adapun ciri-ciri khusus dari handout yang dikembangkan adalah : Handout disesuaikan dengan SK dan KD yang telah ditentukan dalam kurikulum. Uraian materi dibuat mengikuti langkahlangkah model CCT yang dimulai dengan tahap a) orientasi, b) pemunculan gagasan, c) penyusunan ulang gagasan, (i) pengungkapan dan pertukaran gagasan, (ii) pembukaan situasi konflik, (iii) kontruksi gagasan baru dan evaluasi, d) penerapan gagasan, e) mengkaji ulang perubahan gagasan.

Hasil penelitian ini diharapkan dapat dimanfaatkan sebagai berikut ini.

1. Bagi universitas tersedianya handout menggunakan model CCT pada mata kuliah Fisika Dasar.

2. Bagi dosen sebagai bahan pembelajaran mata kuliah Fisika Dasar.
Asumsi dalam pengembangan ini bahwa handout berbasis model CCT dapat mengatasi permasalahan proses pembelajaran dan dapat menyempurnakan buku teks yang ada. Proses pembelajaran yang digunakan dapat memotivasi dan meningkatkan minat mahasiswa serta dapat mengembangkan keterampilan berpikir ilmiah mahasiswa. Agar hasil pengembangan lebih optimal dan terarah, batasan masalah dari pengembangan hanya difokuskan pada pengembangan handout berbasis model CCT pada perkuliahan Fisika Dasar yang dibatasi pada materi suhu dan kalor di STKIP PGRI.

\section{METODOLOGI PENELITIAN}

Penelitian pengembangan adalah penelitian yang bertujuan untuk mengembangkan dan menghasilkan suatu produk berupa materi, media, alat atau strategi pembelajaran yang digunakan untuk menguji suatu teori [3]. Pengembangan modul berbasis model CCT pada perkuliahan Fisika Dasar pada materi suhu dan kalor menggunakan model pengembangan yang dikemukakan oleh [4] yang terdiri dari fase investigasi awal (preliminary research), fase perancangan dan realisasi (prototyping phase), dan fase penilaian (assessment phase).

Langkah-langkah rancangan pengembangan handout ini dimulai dengan melakukan investigasi awal. Setelah dilakukan investigasi awal, tahapan selanjutnya adalah merancang dan mengembangkan handout. Selanjutnya, dilakukan uji coba dan penilaian.

Langkah-langkah rancangan pengembangan handout diatas dapat dirinci sebagai berikut:

a. Fase investigasi awal (preliminary research)

Pada fase ini peneliti melakukan analisis awal atau identifikasi masalah, analisis kebutuhan, analisis konsep atau isi materi, dan pengkajian literatur yang diperlukan dalam pembelajaran. Analisis konsep bertujuan untuk menentukan isi dan materi pembelajaran yang dibutuhkan dalam pengembangan handout. Pada analisis konsep, peneliti melakukan 
identifikasi terhadap konsep esensial dari materi suhu dan kalor. Selanjutnya, dilakukan analisis terhadap karakteristik mahasiswa untuk menentukan model pengembangan handout yang akan digunakan. Selain itu, peneliti juga melakukan kajian terhadap literatur yang tersedia.

b. Fase Perancangan dan Realisasi (prototyping phase)

Pada fase ini dilakukan perumusan atau perancangan terhadap handout. Rancangan handout ini merujuk pada panduan pengembangan bahan ajar yang dikeluarkan oleh [5]. Perancangan bahan ajar meliputi beberapa tahapan, yaitu: (1) mengkaji kesesuaian materi dengan kompetensi dasar yang terdapat dalam kurikulum, menentukan kedalaman materi dan ruang lingkup bahan ajar, (3) menentukan urutan bahan ajar, (4) menentukan jenis perlakuan yang akan diberikan terhadap bahan ajar, (5) menentukan sumber materi pembelajaran. Pada tahapan ini, dilakukan penulisan, penelaahan dan pengeditan handout yang disusun. Perancangan handout dibuat sesuai dengan indikator yang ditetapkan dan berdasarkan format yang disesuaikan dengan kebutuhan peneliti.

Pada fase ini dilakukan formative evaluation yang meliputi self evaluation, expert reviews, one-to-one, dan small group, serta fieldtest. Alur desain untuk formative evaluation ditunjukkan pada Gambar1.

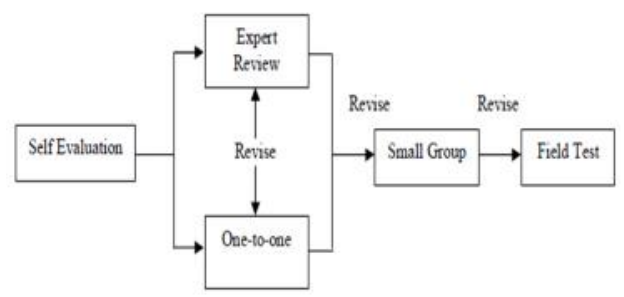

Gambar 1. Alur Desain Formative

1) Self Evaluation Evaluation [6]

Pada tahap ini dilakukan pendesainan handout yang akan dikembangkan. Pendesainan dilakukan berdasarkan hasil analisis awal atau identifikasi masalah, analisis kebutuhan dan analisis konsep atau isi materi, dan pengkajian literatur yang diperlukan dalam pembelajaran.

\section{2) Expert Review}

Pada tahap expert review, dilakukan penilaian dan evaluasi oleh pakar terhadap handout yang telah dirancang. Pakar-pakar tersebut menilai validasi isi, konstruk, dan bahasa. Saran-saran dari para pakar digunakan sebagai acuan untuk merevisi handout yang dikembangkan. Bagian utama yang divalidasi adalah kesesuaian KD, indikator, kebenaran konsep dan bahasa yang digunakan. Masukan dari validator digunakan untuk memperbaiki dan merevisi bahan ajar yang dikembangkan sehingga dihasilkan handout yang valid.

3) One-to-one

Pada tahap one-to-one, dilakukan uji coba desain yang telah dikembangkan kepada mahasiswa dan dosen yang menjadi tester. Hasil dari uji coba ini digunakan untuk merevisi desain yang telah dibuat.

4) Small group

Hasil revisi dari telaah para ahli dan kesulitan yang dialami pada saat uji coba pertama dijadikan dasar untuk merevisi handout tersebut, kemudian hasilnya diujicobakan pada small group. Hasil dari pelaksanaan uji coba ini selanjutnya digunakan untuk revisi sebelum dilakukan ujicoba pada tahap field test. Setelah dilakukan revisi handout berdasarkan saran dan komentar mahasiswa pada small group, diperoleh hasil analisis terhadap handout tersebut.

\section{5) Field Test}

Hasil revisi small group diujicobakan ke subjek penelitian. Uji coba ini merupakan uji lapangan atau field test. Handout yang telah diujicobakan pada uji lapangan adalah handout yang telah memenuhi kriteria kualitas yang meliputi validitas, kepraktisan, dan efektivitas.

c. Fase Penilaian (assessment phase)

Fase ini dilakukan untuk menguji tingkat efektivitas handout. Tahap ini dilakukan untuk mengetahui apakah handout dapat digunakan untuk mencapai tujuan dalam meningkatkan kualitas dan prestasi belajar mahasiswa. Pada penelitian ini efektivitas handout fisika dasar dapat diketahui dari 
aktivitas dan hasil belajar mahasiswa setelah pembelajaran.

\section{HASIL DAN PEMBAHASAN}

Berdasarkan investigasi awal yang dilakukan terhadap mahasiswa maka dilakukan perancangan handout dengan menggunakan model CCT. Berikut ini diuraikan karakteristik handout fisika dasar menggunakan model CCT yang dirancang.

a. Handout yang dirancang memiliki cover dan petunjuk penggunaan. Petunjuk penggunaan menjelaskan langkah dan tujuan setiap fase yang terdapat dalam handout. Contoh halaman petunjuk penggunaan handout

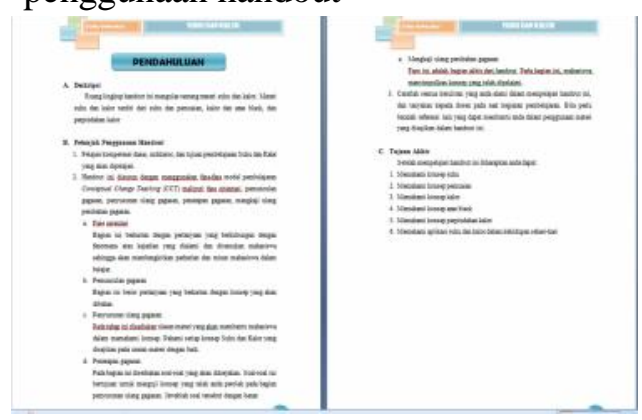

Gambar 2. Contoh halaman petunjuk penggunaan handout

Bagian inti dari handout menunjukkan fase-fase dalam pembelajaran menggunakan model CCT. Fase-fase ini meliputi fase orientasi, pemunculan gagasan, penyusunan ulang gagasan, penerapan gagasan dan mengkaji ulang perubahan gagasan. Berikut ini contoh halaman handout yang memuat fase tersebut.

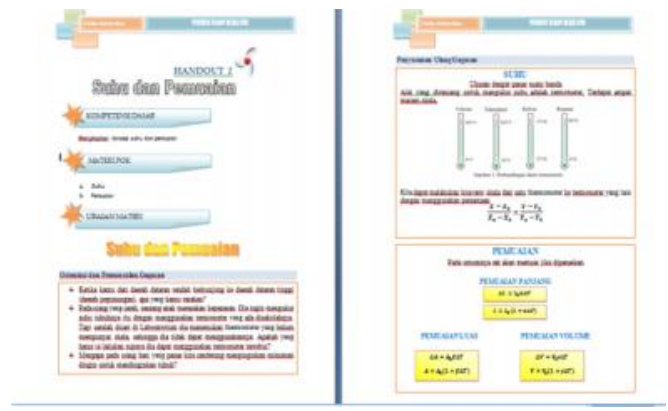

Gambar 3. Contoh halaman handout yang memuat fase tersebut
Handout yang dirancang telah divalidasi oleh 2 orang validator. Handout dinyatakan valid oleh validator setelah dilakukan revisi hasil validasi pertama. Perbaikan dilakukan pada tampilan handout. Berdasarkan hasil validasi pertama, validator menyarankan agar dituliskan keterangan gambar, kemudian tanda baca yang benar, tampilan handout masih cenderung monoton dan kurang menarik sehingga perlu dibuat lebih menarik lagi. Salah satu caranya mengikuti saran dari validator dan memberikan warna yang cerah pada handout.

Validasi handout dilakukan untuk melihat apakah handout sudah valid, baik dari segi isi, konstruksi, maupun bahasa yang digunakan. Handout yang telah valid ini selanjutnya telah dapat digunakan dalam pelaksanaan pembelajaran.

Pengembangan handout menunjang terlaksananya proses pembelajaran yang optimal dan lebih terarah. Handout yang digunakan harus valid sehingga layak digunakan dalam proses pembelajaran. Pada penelitian ini, validasi dilakukan dari segi isi, konstruk, dan bahasa. Dengan demikian, handout yang digunakan dalam kegiatan pembelajaran telah valid. Sebelum melakukan perancangan handout terlebih dahulu dilakukan analisis konsep, analisis karakteristik mahasiswa, dan kajian terhadap literatur yang ada.

Validasi handout menggunakan model CCT dilakukan sebanyak dua kali. Pada validasi pertama ditemukan beberapa kekurangan dari handout yang dirancang. Kemudian, handout tersebut direvisi sesuai saran dari validator. Hasil revisi ini kemudian divalidasi kembali sehingga didapatkan handout dengan kategori sangat valid. Berdasarkan hasil validasi diperoleh nilai persentase rata-rata untuk handout sebesar 94,5\%. Handout dinyatakan valid oleh validator karena handout yang dikembangkan telah sesuai dengan model CCT.

Validasi untuk handout secara garis besar meliputi aspek kelayakan isi, konstruk, dan komponen bahasa yang digunakan. 
Handout yang dikembangkan menyajikan topik yang sesuai dengan tuntutan kompetensi dasar yang telah dirumuskan. Handout juga menyajikan informasi singkat ataupun pertanyaan yang sesuai dengan deskripsi materi suhu dan kalor. Selain itu, isu/masalah yang disajikan dalam handout dikaitkan dengan materi yang dibahas dan dekat dengan lingkungan mahasiswa. Handout juga telah memiliki daftar rujukan yang jelas. Untuk tahap penyusunan ulang gagasan, pernyataanpernyataan yang disajikan dapat membantu mengarahkan mahasiswa dalam membangun pengetahuannya sendiri. Soal-soal yang dirancang membantu mahasiswa dalam mengaplikasikan pengetahuan yang telah mereka bangun. Kemudian, handout juga membantu mahasiswa untuk membuat kesimpulan materi yang dipelajari.

Komponen penyajian handout juga dinilai valid oleh validator. Hal ini karena handout disajikan sistematis mulai dari judul, kompetensi dasar, materi pokok, uraian materi, evaluasi, kesimpulan, dan referensi. Penyajian handout dilakukan secara berurutan sesuai dengan model CCT. Selanjutnya, desain tampilan yang digunakan sederhana dan menarik, bahasa yang digunakan mudah dipahami oleh mahasiswa, dan font yang digunakan jelas dibaca. Penggunaan bahasa dalam handout sudah komunikatif dan jelas. Berdasarkan aspek-aspek yang dinilai tersebut, maka handout yang divalidasi telah dinyatakan valid oleh para validator.

\section{KESIMPULAN}

Berdasarkan hasil penelitian pengembangan handout Fisika dasar menggunakan model CCT pada materi suhu dan kalor, kegiatan yang sudah dilakukan adalah merancang handout berbasis CCT dan melakukan validasi terhadap handout tersebut.

\section{DAFTAR PUSTAKA}

[1]Belawati, T. 2004. Pengembangan Bahan Ajar. Jakarta : Universitas Terbuka.

[2] Lin, Chen-Hu, dkk. 2010. "Utilizing A Concept Map As The Teaching Strategy Based on Conceptual Change Theory For The Course Information Technology and Society". Joint International IGIP-SEFI Annual Conference $2010,19^{\text {th }}-22^{\text {th }}$ September 2010, Timava, Slovakia.

[3]Soenarto. 2005. Metodologi Penelitian Pengembangan untuk Meningkatkan Kualitas Pembelajaran (Research Method The Improvement of Instruction Methodology). Makalah 1-4 Agustus di Denpasar. PPTK dan KPT Depdiknas.

[4]Plomp, Tjeerd. 2010. An Introduction to Educational Design Research. Enschede: University of Twente

[5]Departemen Pendidikan Nasional. 2008. Panduan Pengembangan Bahan Ajar. Departemen Pendidikan Nasional, Direktorat Jenderal Manajemen Pendidikan Dasar dan Menengah, Direktorat Pembinaan Sekolah Menengah Atas.

[6] Tessmer, M. (1998). Planning and Conducting Formative Evaluations. Philadelphia: Kogan Page. 